Исследуя феноменологию постмоды цифровой эпохи, а именно те новые процессы и формы, которые креативные авторы модных предметов представляют на выставках и конгрессах, посвященных инновациям, мы можем ясно увидеть те направления, которые задает мода как актуальная. Заметим также, не разворачивая этот тезис, что сама актуальная эпоха может быть охарактеризована как модная, потому что главная ценность моды - новизна - становится ценностью современной культуры в целом. Для современной модной индустрии характерными оказываются, во-первых, инновационность, основанная на технологии, и креативность, опирающаяся на умение предугадать и создать потребности, что мы можем обозначить как практическую персонализированную инновационность, ориентированную на желания и воображаемые идентичности пользователя. Пользователь же получает возможности сотворчества и самовыражения через предлагаемые модные предметы, «оживляет» их, становясь сокреатором моды как процесса и как явления. Поэтому, во-вторых, мы можем выделить как существенную черту постмоды креативное восприятие инноваций, их адаптацию индивидом под свои нужды, фантазии и самовыражение, внимание к телесным и эмоциональным процессам и готовность быть с ними в контакте, т.е. идентификационные стратегии самовыражения через принятие и изучение инноваций - чего раньше мы не наблюдали в механизмах моды.

Современная постмода использует наши телесные и эмоциональные реакции и на их основе формирует потребности, которые сама же и удовлетворяет. Платья со встреоенными кардиомониторами, детекторами лжи, механическими стимуляторами, мониторами, информационными панелями и самртфонами все это новые эксперименты в области модного воображаемого. Потому что их задача не столько показать, как современные технологии могут использоваться в индустрии моды и что еще дизайнеры могут предложить потребителю, чтобы включить его как можно полнее в дигитальный мир, сколько исследовать, как устроен просьюмер-пользователь, какие эмоциональные активности он переживает, как реагирует, чем интересуется, и дать возможность через модные предметы включить творческую способность, стать соавтором модного продукта, по сути, персонализировав модный гаджет. Таким образом, постмода становится тем, что мы потребляем, и тем, что нас использует, потому что обратная связь неизбежна, и каждое движение, чувство и мысль становятся проявленными благодаря новейшим технологиям, испольуемым дизайнерами. Возникает отчасти идея тотальной слежки, но, по сути, властный взгляд производителей уже давно охватывает всю культуру потребления, однако теперь на место стандартизации пришла персонализация, внимание к индивидуальному, что и делает возможным просьюмерскую активность.

DOI: $10.17223 / 22220836 / 36 / 31$

\title{
Н.И. Басарева
}

\section{КУЛЬТУРА ПОТРЕБЛЕНИЯ И ЗДОРОВЫЙ ОБРАЗ ЖИЗНИ}

Здоровый образ жизни - целесообразная деятельность человека, направленная на сохранение и улучшение его здоровья. Сколько существует человечество, столько же существует проблема укрепления здоровья, стремление 
к физическому совершенству, красоте души, вечной молодости, обладанию сверхчеловеческими возможностями и даже бессмертию. Об этом свидетельствуют предания, сказки, поговорки, песни разных времен и народов мира, дошедшие до наших дней древние философские и медицинские трактаты.

«Совершенство человека - это здоровье; если есть здоровье, то его следует сохранять, а если нет, то следует его приобрести» (Аль-Фараби, 872950 гг. «Указание пути к счастью»). В XXI в. в связи с изменением характера и возрастанием интенсивности нагрузок на организм, увеличением техногенных, экологических, психологических и военных рисков проблема сохранения здоровья является особенно актуальной. Современное общество потребления характеризуется не только массовым потреблением материальных благ, но и соответствующей системой ценностей и установок. Формирование культуры потребления и привитие культурно-гигиенических навыков здорового образа жизни начинается с раннего детства, когда родители организуют окружающую среду ребенка, осуществляют уход за ним, определяют его поведение. В первую очередь семья, а затем и общество формируют систему потребностей, нравственных установок и духовных ценностей. Поэтому вечная проблема выбора для индивида решается посредством сформированной у него культуры потребления в конкретных социально-экономических условиях. Культура потребления решает проблему выбора более качественного, более безопасного для человека и дает знание, как потреблять выбранное без последствий для здоровья. Забота о своем здоровье проявляется через выбор быта, продуктов питания и привычек, более полезных, более здоровых, менее вредных, позволяя скорректировать потребительское поведение в желаемом направлении - в сторону сохранения здоровья и продления активной жизнедеятельности.

В настоящее время среди молодежи растет интерес к здоровому образу жизни, особенно к таким его компонентам, как правильное питание, таймменеджмент, физическая культура и закаливание организма, экология окружающей среды. Культура потребления и здоровый образ жизни - два современных тренда, взаимообусловленных и неразрывно связанных с уровнем качества жизни как индивида, так и общества в целом. При этом оба тренда являются частью общего мегатренда - «стирание граней внутри различных социальных явлений и между ними», в том числе между работой, учебой и частной жизнью, между рабочим местом и жильем, между потребителем и производителем. Среди самой прогрессивной части потребителей появились «профессиональные потребители» и «производители-потребители» - просьюмеры, активно участвующие в процессе производства товаров и услуг, потребляемых ими самими. Представителями просьюмеризма являются и биохакеры - энтузиасты любительских исследований в области биологии, организующие свои домашние или «гаражные лаборатории» (Carlson R., 2005. Splice it yourself). Профессионалы, ведущие на дому собственный проект, и любители объединились в организацию DIY-bio (Do it yourself - «сделай сам»). Они экспериментируют со своим организмом ради его усовершенствования, сохранения молодости и активного долголетия.

Биохакинг - еще один тренд XXI в., пробудивший волну интереса к здоровому образу жизни, на новом уровне развития общества потребления. Программа персонифицированного биохакинга включает в себя: выявление гене- 
тических рисков, правильное питание, умеренную физическую активность, восстановление гормонального баланса, здоровый сон, улучшение мозговой деятельности, избавление от стресса, косметологический уход с использованием новейших достижений науки и современных технологий. Основная задача биохакинга - долголетие и максимальная эффективность организма, развитие всех его функций. Британский геронтолог и автор книги «Отменить старение» Обри ди Грей считает, что победить процессы старения в организме уже сейчас можно с помощью средств современной медицины, и утверждает, что первый человек, который проживет 1000 лет, уже появился на свет. С другой стороны, человек - это не только его биологические показатели. Здоровье человека - это гармоничное единство биологических и социальных качеств, обусловленных его врожденными и приобретенными свойствами. Счастливый и здоровый индивидуум способен прожить многие годы без помощи гаджетов, транквилизаторов и гормональных препаратов.

С прогрессом биохакинга появляется ряд этических вопросов и моральных обязанностей. Кроме максимального продления необходим смысл жизни человека. Многие боятся состариться или потерять трудоспособность и стремятся разными путями достичь совершенства. Одни имплантируют в тело всевозможные гаджеты (гриндеры), другие подробно изучают функции органов, систем, тканей организма для внесения в него положительных изменений с помощью гормонов, фармакологических препаратов и биологически активных добавок, проводят анализ ДНК и генные модификации, эксперименты со стволовыми клетками; самостоятельно создают исследовательское оборудование, в том числе для генетического редактирования. Биохакеры оставляют потребителям их продукции возможность контролировать, настраивать и автоматизировать приобретенную систему. Основные проблемы потребителей - это коммерциализация (образования, инноваций, имиджа, физической культуры и т.д.) и дефицит достоверной информации, а также низкий уровень доказательности эффективности и безопасности многих разработок биохакеров. Опасения в обществе вызывают попытки применения непротестированных и официально не зарегистрированных препаратов для генетического редактирования с целью самолечения, неконтролируемое использование биотехнологий, которое может привести к созданию биологического оружия. Есть также опасения, что существует угроза возникновения диктатуры «сверхчеловеков», как возможный вариант развития олигархического капитализма и общества потребления. Вероятно, об этом предупреждал гениальный И.А. Ефремов в своем социально-философском фантастическом романе «Час Быка» (1968), описывая общество, разделенное на касты «краткожителей», «долгожителей» и «правителей». С другой стороны, есть и позитивные результаты деятельности биохакеров. Положительным примером пользы любительских биотехнологических исследований является создание автоматической инсулиновой помпы - аналога искусственной поджелудочной железы крупным производителем медицинского оборудования Medtronik в сотрудничестве с биохакерами. В 2018 г. аналитический центр Gartner назвал биохакинг одним из пяти ключевых технологических трендов современности. Возможно, в будущем изобретения биохакеров позволят отслеживать показатели организма и предупреждать о болезнях с помощью специальных программ и приложений, а благодаря регенеративной медицине, генной 
терапии и нанотехнологиям появятся реальные возможности жить вечно. Международная некоммерческая организация Humanity+, придерживаясь философии трансгуманизма, занимается продвижением разработок биохакеров с целью улучшить человечество с помощью новых технологий. Трансгуманисты, развивая идею «постчеловечества», считают, что нанотехнологии, биотехнологии и искусственный интеллект, а также полный контроль эмоций и психического состояния освободят место для любви и радости, долгой и здоровой жизни.

DOI: $10.17223 / 22220836 / 36 / 32$

\section{Г.И. Петрова}

\section{О ЧЕМ ПРЕДУПРЕЖДАЛ НАС «МИФ О МИДАСЕ»}

Конечно, «Миф о Мидасе» говорит о жадности, о ненасытной любви к золоту, о богатстве и его пагубности. Откровенный, он лишен рафинированности и рациональной отшлифованности мышления. Наивный и нелогичный, он, однако, дальнозорк, поскольку прозревает будущее не в теоретической редукции, но во всей его живой полноте. И лишь современный читатель в конкретике мифологической эмпирии и описании казалось бы единичных жизненных фактов видит их мудрый и поучительный потенциал. Предупреждающее прозрение «Мифа о Мидасе» становится понятным и актуальным на каждом этапе истории, хотя до сих пор оно (что называется) «не пошло впрок».

Сегодня «Миф» особенно актуален, поскольку нынешняя реальность являет собой откровенный зигзаг, поворот в сторону от истории, которая предполагала онтологически ясное движение, логику, базирующуюся на производстве и традиции как социальном механизме развития. Онтология выстраивалась прочно, логически прозрачно, стабильно. Современный же бегущий мир - это мир неустойчивый и не настоящий, не имеющий прочной основы, как ее не имеет, например, человек, бегущий по тонкому льду. В беге он все превращает в симулякры, в знаки без референта, которые обступают, заменяя подлинность культуры, и в своем пустом множестве предлагаются для ее потребления, но лишь соблазняют, не насыщая. Такой мир чрезвычайно похож на тот, о котором говорит «Миф о Мидасе». Золото не насытило Мидаса, более того, оно было опасно для жизни.

Речь идет об обществе потребления. Как и предрекал «Миф о Мидасе», культура потребления сегодня грозит превратиться в ненасытное потребление культуры. И пока не находится бога Диониса, который, как это случилось с Мидасом, воочию показал бы следствия такого потребления, привел бы нас в чувство. Потребление - жизненная необходимость, но одновременно оно таит в себе и трагическую опасность, если погашено внимание к его культуре, если одна из жизненных ценностей - потребление - противопоставляется в целом ценности жизни.

Тема панельной дискуссии предполагает необходимость ответа на вызовы современной ситуации, когда слишком очевидным стало исчезновение культуры потребления. Обращение к философии в поисках причин того, что 